\title{
Konsumsi Kopi Robusta Menurunkan Kekuatan Tulang Femur Tikus Wistar Jantan
}

\section{(Robusta Coffe Consumption Decrease The Femoral Bone Strength in Rats)}

\author{
Sarah Kinan Andalusia, Muhamad Hasan, Desie Dwi Wisudanti \\ Fakultas Kedokteran Universitas Jember \\ Jl. Kalimantan 37, Kampus Bumi Tegal Boto, Jember 68121 \\ email: sarahqinan@gmail.com
}

\begin{abstract}
Caffeine in coffee is suspected to decrease the bone mineral density and increase the risk factor of osteoporosis, however the contents of coffee is not only caffeine. Considering the great number of people consuming coffee daily, therefore, the study is conducted to investigate the effect of robusta coffee consumption on the femoral bone strength in male wistar rats. Thirty male wistar rats were subjected for the study. They were divided into three groups, i.e control group (K) without robusta coffee consumption, treatment group 1 (P1) with robusta coffee consumption of $0,9 \mathrm{mg} / \mathrm{gBW}$, and treatment group 2 (P2) with robusta coffee consumption of $2,7 \mathrm{mg} / \mathrm{gBW}$. After 21 days, the rats were terminated and the right and the left femurs were collected for force bone test. The force bone test of $P 1$ and $P 2$ group demonstrated weaker bones than $K$ group, and there was no difference effect of $P 1$ group compared to $P 2$ group on the femoral bone strength in male wistar rats. It can be concluded that robusta coffee consumption has negative effect on the bone strenght and hence causing bones more fragile, and there was no difference on effect of $0,9 \mathrm{mg} / \mathrm{g} \mathrm{BW}$ compared to $2,7 \mathrm{mg} / \mathrm{g} B W$.
\end{abstract}

Keywords: coffee, strength, bone

\begin{abstract}
Abstrak
Kafein dalam kopi diduga menurunkan kepadatan mineral tulang dan meningkatkan faktor risiko osteoporosis, namun kandungan dalam kopi tidak hanya kafein. Mengingat, banyaknya orang yang mengkonsumsi kopi sehari-hari, oleh karena itu, tujuan dari penelitian ini adalah untuk membuktikan pengaruh konsumsi kopi robusta terhadap kekuatan tulang femur tikus wistar jantan. Tiga puluh tikus wistar jantan yang telah dipilih untuk penelitian, dibagi dalam tiga kelompok $(n=10)$, yaitu, kelompok kontrol $(K)$ tanpa konsumsi kopi robusta, kelompok perlakuan 1 (P1) konsumsi kopi robusta dosis $0,9 \mathrm{mg} / \mathrm{g}$ BB, dan kelompok Perlakuan 2 (P2) konsumsi kopi robusta dosis 2,7 mg/g BB. Setelah 21 hari, tikus diterminasi dan diambil sampel tulang femur kanan dan kiri untuk dilakukan uji kuat tekan tulang. Kuat tekan tulang pada kelompok P1 dan P2 terbukti lebih lemah daripada kelompok K, serta tidak ada perbedaan pengaruh pada kelompok P1 dibandingkan P2 terhadap kekuatan tulang femur tikus wistar jantan. Dapat disimpulkan bahwa konsumsi kopi robusta mempunyai pengaruh negatif terhadap kekuatan tulang dan menyebabkan tulang lebih rapuh, serta tidak terdapat perbedaan antara konsumsi kopi dosis $0,9 \mathrm{mg} / \mathrm{g}$ BB dibandingkan dengan dosis $2,7 \mathrm{mg} / \mathrm{g}$ BB.
\end{abstract}

Kata kunci: kopi, kekuatan, tulang 


\section{Pendahuluan}

Konsumsi kopi sudah menjadi kebiasaan sehari-hari bagi banyak orang, bahkan di beberapa negara sudah menjadi tradisi termasuk di Indonesia. Kopi yang ditanam di Indonesia adalah kopi arabika dan robusta, di Jawa Tengah pada umumnya adalah kopi arabika, sedangkan di Jawa Timur adalah kopi robusta [1]. Jenis kopi yang ditanam di Kabupaten Jember merupakan jenis robusta [2]. Menurut International Coffee Organization (2011), kopi adalah sumber utama dari kafein. Kopi arabika mengandung kafein 0,8-1,4\%, sedangkan kopi robusta mengandung kafein $1,7-4,0 \%$, maka kandungan kafein pada kopi robusta lebih tinggi daripada kopi arabika.

Kafein berhubungan dengan kerusakan keseimbangan kalsium. Konsumsi kafein > 300 $\mathrm{mg} /$ hari meningkatkan konsentrasi kalsium pada urin dan plasma, menurunkan kepadatan mineral tulang dan menurunkan volume tulang pada wanita postmenopausal [3]. Hal ini menunjukkan bahwa kafein berhubungan dengan penurunan kepadatan mineral tulang yang menyebabkan kekuatan tulang menurun dan meningkatkan faktor risiko terjadinya osteoporosis [3].

Osteoporosis dapat dijumpai di seluruh dunia dan sampai saat ini masih merupakan masalah dalam kesehatan masyarakat terutama di negara berkembang. Mengutip data dari WHO (2004) bahwa di seluruh dunia ada sekitar 200 juta orang yang menderita osteoporosis [4].

Pada penelitian sebelumnya yang pernah dilakukan pemberian kafein dosis 0,005-0,1 mM selama 24 jam yang dilakukan dalam penelitian in vitro dapat memicu peningkatan diferensiasi sel osteoklas melalui peningkatan Receptor Activator of Nuclear Factor Kappa $\beta$ Ligand (RANKL). RANKL mediator yang dikeluarkan oleh osteoblas, yang dapat mempengaruhi diferensiasi awal osteoklas, sehingga proses resorpsi tulang lebih banyak daripada proses pembentukan tulang [5]. Pada penelitian yang dilakukan secara in vivo pada tikus wistar jantan dengan konsumsi kafein sebanyak $22 \mathrm{mg} /$ hari dan $44 \mathrm{mg} / \mathrm{hari}$ selama $20 \mathrm{minggu}$, terjadi penurunan Bone Mineral Density (BMD) karena adanya peningkatan osteoklastogenesis, sehingga aktivitas resorpsi tulang juga meningkat [5]. Hasil dari penelitian tersebut menunjukkan bahwa dosis kafein dalam kopi berbanding lurus dengan besarnya penurunan kekuatan tulang.
Penelitian eksperimental mengenai pengaruh kopi terhadap tulang yang pernah dilakukan yaitu penelitian tentang pengaruh kopi terhadap sel tulang dengan menggunakan parameter histologi, sedangkan penelitian yang menggunakan parameter kekuatan tulang masih sedikit diteliti dan belum pernah ada yang menggunakan alat uji kuat tekan beton digital. Kandungan di dalam kopi tidak hanya kafein, bahkan sebagian kandungan kopi diperkirakan dapat meningkatkan kekuatan tulang dan sebagian yang lain diperkirakan dapat menurunkan kekutan tulang, meskipun diketahui bahwa kandungan kopi robusta yang paling tinggi adalah zat yang diperkirakan dapat menurunkan kekuatan tulang. Kandungan kopi yang diperkirakan dapat menurunkan kekuatan tulang selain kafein adalah natrium, fosfor, karbohidrat dan gula, serta protein. Oleh karena itu tujuan dari penelitia ini adalah untuk membuktikan pengaruh konsumsi kopi robusta terhadap kekuatan tulang femur tikus wistar jantan.

\section{Metode Penelitian}

Pada awal penelitian dilakukan pemilihan tikus putih wistar jantan sebanyak 30 ekor, lalu disiapkan kandang tikus dengan ukuran $30 \mathrm{~cm} \mathrm{x}$ $30 \mathrm{~cm}$ dengan jumlah tikus sebanyak 5 ekor dalam satu kandang, tikus di adaptasi dengan diberikan pakan standar dan minum akuades ad libitum selama 23 hari. Setelah dilakukan adaptasi selama 23 hari, lalu tikus dilakukan penimbangan lagi dan dilakukan randomisasi dengan menggunakan Stratified Random Sampling. 30 tikus tersebut dibagi menjadi 3 kelompok yaitu kelompok kontrol (K) tanpa konsumsi kopi robusta, kelompok perlakuan 1 (P1) konsumsi kopi robusta dengan dosis 0,9 $\mathrm{mg} / \mathrm{g}$ BB, dan kelompok perlakuan 2 (P2) konsumsi kopi robusta dengan dosis $2,7 \mathrm{mg} / \mathrm{g}$ BB.

Setelah 21 hari tikus diberi perlakuan, tikus pada seluruh kelompok penelitian diterminasi menggunakan anestesi kloroform secara inhalasi, kemudian dilakukan pengambilan sampel tulang femur kanan dan kiri yang diambil secara posisi anatomis dengan ukuran panjang mulai dari batas atas caput femoris sampai batas bawah condylus lateralis. Lebar femur adalah hasil pengukuran diameter corpus femur (pertengahan dari panjang femur) 
yang diukur secara posisi anatomis, kemudian langsung diukur kekuatan tulangnya dengan menggunakan alat uji kuat tekan beton dalam satuan megapascal (MPa). Seluruh sampel diterminasi dalam satu waktu, tetapi dilakukan pengambilan sampel dan pengujian kuat tekan tulang satu per satu agar sampel tidak terkontaminasi oleh lingkungan luar untuk menghindari adanya bias. Setelah dilakukan pengujian, sampel tulang femur tikus dikubur.

Penelitian ini telah disetujui oleh Komisi Etik Fakultas Kedokteran Universitas Jember dengan nomor surat 1022/H25.1.11/KE/2016 pada tanggal 2 November 2016.

\section{Hasil Penelitian}

Pada penelitian ini dilakukan penimbangan berat badan (BB) tikus tiap satu minggu sekali, penimbangan massa sampel tulang, dan luas permukaan sampel tulang femur tikus wistar jantan. Kemudian dilakukan uji Anova dan tidak didapatkan perbedaan yang signifikan antar kelompok. Hal tersebut menunjukkan bahwa bias dalam penelitian ini sudah dikendalikan.

Berdasarkan data nilai kuat tekan tulang femur tikus wistar jantan yang disajikan pada Tabel [1], kemudian dilakukan uji normalitas dengan Kolmogorov-Smirnov d a $\mathrm{n}$ u j i homogenitas dengan Levene's test sebagai syarat sebelum melakukan uji parametrik. Hasil analisis data nilai kuat tekan tulang femur tikus wistar jantan dari ketiga kelompok menunjukkan data terdistribusi normal $(p>0,05)$ dan homogen $(p>0,05)$. Setelah memenuhi syarat uji parametrik, dilanjutkan dengan uji One-way Anova. Hasil dari uji One-way Anova didapatkan $\mathrm{p}<0,05$ yang berarti terdapat minimal 2 kelompok yang memiliki perbedaan signifikan. Untuk mengetahui lebih lanjut perbedaan antar kelompok, kemudian dilakukan uji post hoc test dengan menggunakan Least Significance Difference (LSD). Hasil dari uji LSD menunjukkan adanya perbedaan yang signifikan antara kelompok $K$ dengan $P 1 \quad(p<0,05)$ dan antara kelompok K dengan P2 $(p<0,05)$, serta tidak didapatkan perbedaan yang signifikan antara kelompok P1 dengan P2 $(p>0,05)$.
Tabel [1] Nilai rata-rata kuat tekan tulang femur tikus wistar jantan pada masingmasing kelompok

\begin{tabular}{|c|c|}
\hline Kelompok & $\begin{array}{l}\text { Nilai Rata-Rata Kuat Tekan } \\
\text { Tulang }(X \pm S D)(\mathrm{MPa})\end{array}$ \\
\hline kontrol (K) & $155286,7521 \pm 9588,112368$ \\
\hline perlakuan $1(\mathrm{P} 1)$ & $145329,8274 \pm 9614,133799$ \\
\hline perlakuan 2 (P2) & $144911,1090 \pm 5616,235579$ \\
\hline $\begin{array}{ll}X & : \text { nilai rata } \\
\mathrm{SD} & : \text { standar } \\
\mathrm{MPa} & : \text { megapas }\end{array}$ & $\begin{array}{l}\text {-rata kuat tekan tulang } \\
\text { deviasi } \\
\text { scal }\end{array}$ \\
\hline
\end{tabular}

\section{Pembahasan}

Penelitian ini bertujuan untuk mengetahui pengaruh konsumsi kopi robusta terhadap kekuatan tulang femur tikus wistar jantan. Berdasarkan hasil pengujian yang telah dilakukan terhadap sampel tulang femur tikus wistar jantan didapatkan nilai rata-rata kuat tekan tulang femur tikus wistar jantan pada kelompok perlakuan (P1, P2) yang mengkonsumsi kopi robusta menunjukkan nilai yang lebih rendah daripada kelompok kontrol (K). Hasil dari penelitian ini menunjukkan bahwa konsumsi kopi robusta dapat menurunkan kekuatan tulang. Hasil tersebut sesuai dengan penelitian serupa yang pernah dilakukan mengenai efek konsumsi kopi (Coffea arabica) terhadap biomekanika tulang femur pada tikus yang diberi konsumsi kopi selama 60 hari [6]. Penelitian tersebut membuktikan bahwa biomekanika pada sifat mekanis tulang femur dengan pengujian Three Point Bending Test pada kelompok perlakuan yang diberi konsumsi kopi arabika secara signifikan lebih rapuh dibandingkan dengan kontrol.

Biomekanika terbagi menjadi 2 yaitu struktur mekanis tulang (ukuran, volume, arsitektur tulang) dan sifat mekanis tulang (sel, matriks organik, matriks anorganik tulang) [6]. Hal tersebut sesuai dengan hasil uji Anova dalam penelitian ini yang menunjukkan bahwa tidak terdapat perbedaan yang signifikan pada penimbangan berat badan (BB) tikus minggu 1 , minggu 2, dan minggu 3 , serta pada penimbangan massa sampel tulang dan luas permukaan sampel tulang femur tikus wistar 
jantan. Hal tersebut menunjukkan bahwa tidak terjadi penurunan kekuatan tulang melalui perubahan struktur mekanis tulang, tetapi melalui perubahan sifat mekanis tulang yang diduga disebabkan oleh salah satu unsur sifat mekanis tulang yaitu matriks anorganik yang salah satunya adalah kalsium.

Kopi robusta memiliki kandungan yang dapat menurunkan kekuatan tulang, salah satunya adalah kafein. Kandungan kafein dalam kopi robusta sebesar 1,6-2,4\% [7]. Berdasarkan penelitian sebelumnya yang pernah dilakukan mengenai pengaruh kafein terhadap peningkatan diferensiasi sel osteoklas secara invitro dan penurunan Bone Mineral Density (BMD) secara invivo pada tikus, terbukti bahwa pemberian kafein dosis rendah $(0,005-0,1 \mathrm{mM})$ selama 24 jam secara invitro, signifikan meningkatkan diferensiasi sel osteoklas dan meningkatkan pit formation assay yang digunakan sebagai marker dari aktivitas resorpsi tulang, serta meningkatan Receptor Activator of Nuclear Factor Kappa $\beta$ Ligand (RANKL). RANKL merupakan mediator yang dikeluarkan oleh osteoblas, yang dapat mempengaruhi diferensiasi awal osteoklas, sehingga proses resorpsi tulang akan meningkat [5]. Sedangkan pada penelitian yang dilakukan secara in vivo pada tikus wistar jantan dengan konsumsi kafein sebanyak $22 \mathrm{mg} /$ hari dan $44 \mathrm{mg} /$ hari selama 20 minggu, terjadi penurunan secara signifikan pada BMD dan kalsium tulang yang disebabkan oleh peningkatan osteoklastogenesis, sehingga aktivitas resorpsi tulang juga meningkat [5]. Hasil dari penelitian tersebut menunjukkan bahwa semakin besar dosis kafein dalam kopi maka semakin besar penurunan kekuatan tulang yang terjadi.

Ada beberapa kesulitan dalam proses penelitian ini, yang pertama pada proses perlakuan sonde lambung kelompok perlakuan. Sediaan kopi robusta menghasilkan ampas kopi yang bisa menyumbat sonde lambung, sehingga digunakan alat alternatif dengan cara membuat sonde lambung menggunakan sedotan yang disambungkan dengan syringe, tetapi karena ukurannya lebih besar dibandingkan sonde lambung yang asli maka lebih susah untuk memasukkan ke dalam saluran pencernaan tikus. Kesulitan kedua, tikus pada kelompok perlakuan yang diberi konsumsi kopi robusta berperilaku lebih agresif daripada tikus pada kelompok kontrol, yang menyebabkan tikus yang satu menyerang tikus yang lain dan lebih sulit untuk dilakukan sonde lambung. Kesulitan ketiga, pada proses pengambilan sampel dan pengujian kuat tekan tulang harus dilakukan satu per satu tiap sampel. Hal ini menyebabkan butuh waktu yang lama antara pengujian kuat tekan tulang sampel yang satu dengan sampel yang lain, sehingga mesin uji kuat tekan beton harus dimatikan selama proses pengambilan sampel tulang dan dinyalakan lagi saat akan menguji kuat tekan tulangnya, untuk menghindari ketidakakuratkan data yang dapat disebabkan oleh mesin uji kuat tekan beton yang panas. Hal ini menyebabkan proses penelitian menjadi kurang efektif dan efisien.

\section{Simpulan dan Saran}

Berdasarkan penelitian yang telah dilakukan, dapat disimpulkan bahwa konsumsi kopi robusta dapat menurunkan kekuatan tulang femur tikus wistar jantan secara signifikan $(p<0,05)$ dan tidak terdapat perbedaan antara konsumsi kopi robusta dengan dosis $0,9 \mathrm{mg} / \mathrm{g}$ BB dibandingkan dengan konsumsi kopi robusta dengan dosis 2,7 mg/g BB.

Saran dalam penelitian ini adalah yang pertama perlu penelitian lebih lanjut menggunakan metode yang berbeda dengan variasi dosis kopi yang lebih banyak dalam jangka waktu lebih lama, yang kedua sebaiknya pengambilan semua sampel dilakukan secara bersamaan di awal dan setelah itu dilanjutkan dengan pengukuran kekuatan tulang agar lebih efektif dan efisien, dan yang ketiga sebaiknya dalam setiap kandang hanya hanya diisi satu hewan coba agar pemberian makan dan minum sama, perkembangan masing-masing hewan coba dapat dipantau, serta mencegah adanya hewan coba yang mati disebabkan hewan coba lain.

\section{Daftar Pustaka}

[1] Rahardjo P. Kopi Panduan Budidaya dan 
Pengolahan Kopi Arabika dan Robusta. Jakarta: Penebar Swadaya; 2012.

[2] Pusat Penelitian Kakao Indonesia. Press Conference ASIC (Association for Science and Information on Coffee) Coffee and Health. Jember: Pusat Penelitian Kakao Indonesia; 2010.

[3] Kartikaningtyas AD. Efek Kafein terhadap Jumlah Sel Osteosit pada Daerah Tekanan Tulang Alveolar Gigi Tikus yang Diiunduksi Gaya Ortodonti. Skripsi. Jember: Fakultas Kedokteran Gigi Universitas Jember; 2016.

[4] Pusparani TF. Efek Kafein Terhadap Jumlah Osteoblas pada Tulang Alveolar Daerah Tarikan Gigi Marmut (Cavia cobanya) Jantan yang Diinduksi Gaya Mekanis Ortodonti. Skripsi. Jember: Fakultas Kedokteran Gigi Universitas Jember; 2016.
[5] Liu SH, Chinliang C, Sen YR, Yen YP, Ting YY, dan Chingmin T. Caffeine Enhances Osteoclast Differentiation from Bone Marrow Hematopoietic Cells and Reduces Bone Mineral Density In Growing Rats. Journal of Orthopaedic Research; 2011; 29 (6): 954960.

[6] Santos MP, Pagani JCM, Silva TD, Garcia JAD, Romao MOC, Fernandes GJM, dan Soares EA. Effects of Coffee (Coffea arabica) Consumption on The Femoral Morphology and Biomechanics in Rats. Journal Morphology Science; 2014; 31 (1): 42-47.

[7] Alvira F. Pengaruh Pemberian Kafein Terhadap Jumlah Pembuluh Darah pada Ligamen Periodontal Tikus yang Diinduksi Gaya Ortodonti. Skripsi. Jember: Fakultas Kedokteran Gigi Universitas Jember; 2016. 